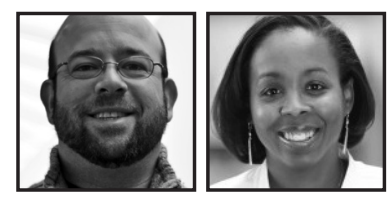

\title{
The Production, Consumption, and Sharing of Art, Knowledge, and Benefits Within the Network of a University-Community Choir
}

Adam Adler and Natalya R. Brown, Nipissing University

\begin{abstract}
A university-community choir is a hybrid of an institutional choir and a community choir, facilitating the creation, consumption, and sharing of art, culture, knowledge, and wealth between its various stakeholder groups. We surveyed and interviewed a variety of stakeholders of a university-community choir to illuminate the mutually beneficial relationships that exist between them. The benefits of the universitycommunity choir include enabling the artist-researcher-teacher, keeping music in postsecondary liberal arts education, facilitating lifelong music learning and serious leisure, and cultivating future artists. We demonstrate the value of such an organization, as it bridges the university-community divide through music education.
\end{abstract}

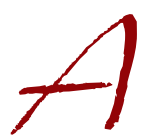

university-community choir is a hybrid ensemble combining attributes of both institutional and community choirs, that facilitates the creation, consumption, and sharing of art, culture, knowledge, and wealth between a wide range of stakeholder groups: the university, students, staff, and faculty members, community members, donors, volunteers, community partners, audience members, and the local arts community. The goal of this paper is to demonstrate the value provided by such an organization, as it bridges the universitycommunity divide through music education.

The many benefits of music education for youth and adults (e.g., self-esteem, self-discipline, creativity, musical ability, social and personal skills, reading and 
arithmetic skills, love of music, self-expression, and sense of belonging) have been discussed extensively in the literature (Douglas \& Willatts, 1994; Gardiner, Fox, Knowles, \& Jeffrey, 1996; Hetland, 2000; Kokotsaki \& Hallam, 2007; Schellenberg, 2004). As cuts to funding, curricular time, and the quality of music instruction at elementary and secondary schools threaten the sustainability of music programs across Canada (A Delicate Balance, 2010), community music programs and ensembles fill the gap for some youth by providing opportunities for musical engagement and learning. These youth music programs are often led by the same music educators who are teaching music within the public school system (Beynon, 2003). Opportunities for postsecondary music education and performance are primarily provided by universities and colleges (for postsecondary students) and by community music ensembles (for working adults and retirees). However, opportunities can be lacking for postsecondary students who are not pursuing music as their degree focus, or for students at institutions without music programs. The tower-and-town gap can also limit postsecondary students' awareness of music opportunities in the communities that house their universities and colleges.

Recognizing the importance of musical engagement to quality of life and well-being, community music ensembles provide enriching music education and performance experiences for their members, while the music they create provides music education and enjoyment for community audiences. The relative weight given to performance versus music education can vary among these ensembles. Individuals who participate in community music ensembles are engaged in serious leisurea systematic pursuit requiring the dedication of time and effort commensurate with a career, that provides "personal fulfillment, identity enhancement, self-expression" (Stebbins, 1982, p. 253). Given the constraint of strong competition for talent (singers and conductors), funding, and resources, some community music ensembles need to form partnerships and develop strong networks in order to survive.

Meanwhile, universities are challenged to connect to the communities they inhabit in order to recruit students, raise funds, and maintain public support. Although universities have a positive economic development effect on the communities in which they reside, their relationships with the communities are often not free of conflict (Kemp, 2014). There is increased pressure on universities to show that their interests are aligned with the communities that house them (Mullin, Kotval-K, \& Cooper, 2012). In addition, faculty members within universities need to demonstrate to the community the purpose and value of a significant, but often less visible part of their workload-research, scholarly, and creative activity, as well as campus and/or community service. Knowledge mobilization 
must extend beyond academia in order to maintain strong town-and-gown relations and to fulfill the university's civic responsibilities.

In this paper, we examine closely the operations of a university-community choir (UCC) - Near North Voices (NNV) - in order to illuminate the mutually beneficial relationships that exist between its diverse stakeholders and to demonstrate the value provided by such an organization. Surveys of and interviews with past and present choir members, donors, volunteers, audience members, and community partners of NNV clarified the contributions of and the value derived by these stakeholders from their relationship with this UCC. We discuss how a UCC can satisfy community demand for music education while simultaneously satisfying a university's need for stronger town-and-gown relations and opportunities for research, scholarly work, creative activities for faculty, and while solving some of the operational challenges experienced by some community choirs. We illustrate how a UCC can bolster the postsecondary education system capacity for knowledge mobilization and research application.

\section{Related Literature}

Mayfield (2010) advocates that universities that are engaged with the community are better able to weather the general criticism that universities ignore the interests and concerns of the community despite receiving public support. Universities that have developed community partnerships have enhanced quality of life in the community by providing educational, social, and recreational programs (Mullins \& Gilderbloom, 2002). Research that examines university-community engagement from the point of view of community members who are given access to the university is limited, but necessary (Bruning, McGrew, \& Cooper, 2006). Bruning and colleagues (2006) explore the benefits that may accrue to a university when community members are invited to partake of the university's cultural, intellectual, athletic, and artistic resources and find that individuals who had attended a university event were significantly more likely to view the university positively on the dimensions of trust and openness. Finally, Kemp (2014) argues that community and university partnerships lead to better planning and management of their respective resources.

Music education researchers have attributed many social and psychological benefits, such as improved self-esteem and sense of self, a sense of belonging, 
and the creation of safe places to participation in school music communities (Adderley, Kennedy, \& Benx, 2003; Freer, 2009; Freer \& Tan, 2014; Kennedy, 2004; Parker, 2014; 2016). Community choirs provide opportunities to continue lifelong musical education and contribute to the artistic vitality of communities (Sayer, 2010). Veblen and Olsson (2002) argue that community music organizations are an essential part of a community's social and cultural fabric. In an examination of a community choir, Langston and Barrett (2008) find evidence of social capital formation indicators: trust, participation, interaction, civic and community involvement, friendship, cooperation, networks, obligation and reciprocity, shared values and norms, learning, and fellowship.

Meisenbach and Kramer (2014) explored the role of identity in the voluntary membership of a community choir and found that choir members identified strongly with the community choir and viewed their active participation as a means of "enacting nested identities" (p. 196) of choir, music, and family. Membership in community choirs has been shown to provide improved vitality, social function, mental health, and quality of life of older adults and for those coping with serious illnesses such as cancer (e.g., Davis, 2012; Johnston et al., 2013). Educational activities and music-making can provide seniors with opportunities to remain physically, mentally, and socially active and improve overall well-being (Joseph \& Southcott, 2015; Macdonald, 2013; McQueen, Hallam, Greech, \& Vavarigou, 2013). Skingley and Bungay (2010) found that singing was associated with a wide range of benefits for seniors.

The very nature of a university-community choir means that members of different backgrounds are brought together to perform. Darrow, Johnson, and Ollenberger (1994) found that combining choristers of different generations and with different objectives (e.g., university students seeking credits, seniors seeking recreational opportunities) had positive effects. Bowers (1999) found evidence of positive attitudinal effects among members of an intergenerational choral ensemble. Conway and Hodgman (2008) studied the experiences of members of a college choir and a community choir who collaborated in an intergenerational performance project and found that the collaboration heightened the performance experience of the members, facilitated better understanding of others, and diminished or eliminated the age barrier.

Along with differences in age and purpose, there are differences in skill and experience among members of a university-community choir. The professional and semi-professional members of the ensemble are able to mentor the less 
experienced members and model performance standards and behaviours (Liu \& Stebbins, 2014). There is limited research on concert singing as a leisure activity; the costs, constraints, and facilitators have not been fully explored in the context of an institutional chorus (Liu \& Stebbins, 2014). According to Liu and Stebbins (2014), there are six main characteristics of serious leisure:

- The need to persevere;

- Finding a career in the activity, with turning points and stages of achievement or involvement;

- Significant personal effort;

- Durable benefits (e.g., self-development, self-expression, renewal, social interaction, and sense of belonging)

- A unique ethos that grows up around the serious leisure activity, with a social world as a central component; and

- Strong identification with the chosen activity.

\section{The University-Community Choir (UCC)}

The UCC is a hybrid ensemble combining traits of an institutional choir and a community choir. An institutional chorus is found in an educational setting (e.g., university, college, high school) or a large business or a unit of government. The musical experience and skill of members of an institutional or community chorus may range from professional concert singers to neophyte amateurs (Liu \& Stebbins, 2014). Universities with music programs commonly offer choir/chorus as credit course for music students. The practice of opening membership in choral ensembles to non-music students (including for credit) is common practice in the United States, but is much less common in Canada. Even less common in Canada is the practice of opening university ensembles to participation by university faculty and staff, or to members of the (non-university) local community. As a community choir, the UCC welcomes participation by members of the local community.

The first author established Near North Voices (NNV) - North Bay's UniversityCommunity Choir-in 2007 as an advanced choir to serve students, staff, and faculty at Nipissing University and Canadore College, the neighboring college. Membership was opened to members of the North Bay community in 2008, and the ensemble has since grown from a founding group of 17 to a membership 
of over 40 with an age range of 15 to 81 . NNV is a noncompetition choir that requires minimal auditions to join. The choir is run by the first author, as artistic director, and by a subgroup of choristers, acting as an advisory group. Choir practices occur weekly during the academic year and the choir performs two concerts per year on average. North Bay is a known retirement community, with a higher proportion of seniors in the population than the national average (Statistics Canada, 2012). Not surprisingly, the two largest age groups represented in NNV are university and college students and young working adults, typically aged 18 to 29 , and individuals 50 years of age and older. Also stable is the membership breakdown between university students and community members, with students and community members comprising one-third and two-thirds of the membership, respectively.

In the absence of a curricular music program at Nipissing University, NNV provides opportunities for music learning through the performance of challenging choral art music. The mission of this ensemble is to educate, inform, and entertain the Nipissing University and North Bay communities, while also seeking to question existing practices and to trouble static beliefs around music making and choral art in North Bay and area. NNV has served to bridge "tower and town," bringing the community to campus, and university research, scholarly and creative activity (along with postsecondary students, staff, and faculty) into the community.

\section{Data and Methodology}

As previously stated, a university-community choir (UCC) has a broad range of stakeholders. Figure 1 illustrates this and was used as the conceptual framework for interpreting our findings. The two-way arrows linking the UCC to its various stakeholder groups reflect the complexity and mutually beneficial nature of each relationship. Given the rarity of university-community choirs across Canada, we focused our attention on one such choral ensemble in one community. We received approval from our university's research ethics board to collect three types of data: surveys of stakeholders, interviews with key members of the choral ensemble, and the choral ensemble's programmatic and financial documentation. 


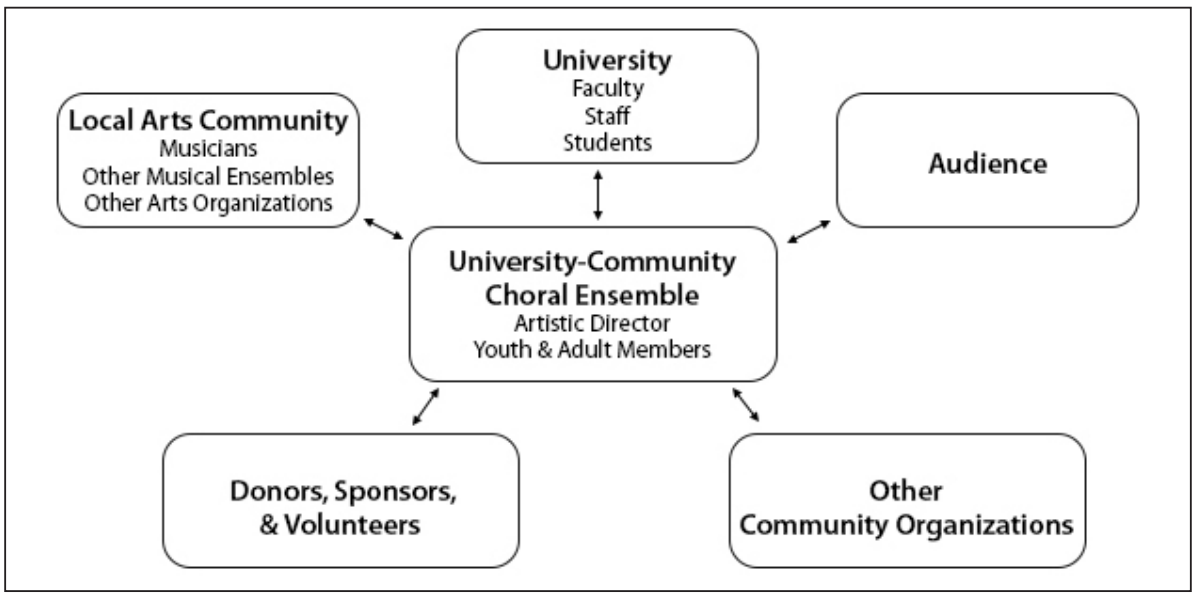

Fig. 1: University-community choir stakeholders

The survey instrument used to collect data on the perceptions of stakeholders of their contributions to and the value they received from their relationship with the UCC was developed with the various roles and characteristics of stakeholders in mind. The survey was administered online through Fluid Surveys in March and April of 2015. Past and present members, guest musicians, donors, community partners, and volunteers of NNV were sent an email through the choir's email distribution list. An invitation and link to the survey was also posted on the choir's website in the members-only area. At the time of the survey, NNV had 67 past choristers and 56 current choristers. Over the years, NNV has worked with 53 instrumentalists and vocalists, and has approximately two-dozen community partners, donors, and volunteers. The response rate for choristers was $45 \%$, with 55 past and present choristers participating in the survey. Eleven donors, corporate sponsors, and volunteers participated, for an approximate response rate of $46 \%$. Finally, 19 instrumentalists and guest vocalists participated, for a response rate of $36 \%$.

Survey participants were asked questions to capture the many ways they have contributed time and money to the UCC. For example, choristers were asked, "What is your perception of your contribution to the group?", "What is the benefit to you for participating?" and "What is the benefit of your participation to the surrounding community?" Choristers and volunteers were asked to approximate the number of hours they had contributed to their last NNV concert, including involvement leading up to, during, and following the concert. A traditional approach in the recreation demand literature is to use a fraction of the average wage as the value of time (e.g., Bowker, English, \& Donovan, 1996; Phaneuf, 1999). Often the range of the fraction used is one-quarter to one-half of the wage rate (Cesario, 1976). We used one-half or one-quarter of the wage rate indicated by participants in our 
calculations to estimate the value of volunteer/leisure time devoted to the UCC. The drawbacks to this way of valuing leisure time are that it may not fully account for the way time values are likely to vary across individuals and that for a given individual, time may be valued differently according to how it is spent (Larson, Shaikh, \& Layton, 2004). However, this was the most accessible method given our diverse group of stakeholders and we were concerned with aggregate rather than individual values. Donors and community partners were asked, "How do you think you and/or your organization contribute to Near North Voices?" and "How do you think you and/or your organization benefit from involvement with Near North Voices?" Demographic data on the participants were also collected; in particular, their gender, age group, and level of education.

The qualitative data from the responses to open-ended questions from the survey were read thoroughly by both authors, and themes related to the benefits from and the contributions of participants to the UCC were generated deductively, that is, directed by our understanding of existing stakeholder relationships and concepts such as serious leisure. In addition, in order to gather rich data about contributions, benefits, and experiences, semi-structured face-to-face interviews were conducted with four advisory group members of the UCC, and its artistic director. Interviews were audio recorded and then transcribed. Each transcript was read thoroughly by both authors. Perspectives and experiences that articulated the participants' benefits from and contributions to the UCC were chosen as themes. The same thematic analysis used for the qualitative data from the survey was utilized here. Both authors classified the themes separately, then compared them to improve reliability, and reached a consensus as to which themes most closely portrayed the participants' experiences and agreed on codes (Patton, 1990). The data was then reread and sorted by theme (Bogdan \& Biklen, 2007).

Interview participants were asked to disclose the nature and extent of their contributions to the organization. In addition, they were asked about the organization's decision-making structure, mission, and long-term goals and about the nature of their relationships with other musical ensembles and community organizations. For example, interview participants were asked, "What do you consider to be Near North Voices' mission?" and "What goals do you think Near North Voices as an organization is trying to achieve?" Table 1 shows the breakdown of participants by role, gender, and age. We conducted a content analysis of the concert programs to determine the level of music education and the amount of knowledge transfer that occurred. Finally, we examined financial records of the last six seasons of the UCC to ascertain the relative importance of various funding sources and costs associated with membership, concerts, and rehearsals. All fees and cost estimates are given in Canadian dollars. 
Table 1

\section{Survey and Interview Participants}

\begin{tabular}{|c|c|}
\hline SURVEYS & NO. OF SURVEY PARTICIPANTS \\
\hline \multicolumn{2}{|c|}{ PRIMARY ROLE } \\
\hline Choristers & 55 \\
\hline Orchestra Members \& Guest Soloists & 19 \\
\hline Donors & 5 \\
\hline Community Partners \& Volunteers & 6 \\
\hline \multicolumn{2}{|c|}{ GENDER } \\
\hline Male & 29 \\
\hline Female & 57 \\
\hline \multicolumn{2}{|c|}{ AGE } \\
\hline $18-29$ years & 26 \\
\hline $30-39$ years & 9 \\
\hline $40-49$ years & 14 \\
\hline 50 years and over & 35 \\
\hline
\end{tabular}

INTERVIEWS

NO. OF INTERVIEW PARTICIPANTS

\begin{tabular}{|l|c|}
\hline \multicolumn{2}{|c|}{ CHORAL GROUP } \\
\hline UCC & 5 \\
\hline Other Community Choral Group & 6 \\
\hline \multicolumn{2}{|c|}{ GENDER } \\
\hline Male & 2 \\
\hline Female & 9 \\
\hline & AGE \\
\hline 18-29 years & 2 \\
\hline 30-39 years & 2 \\
\hline 40-49 years & 3 \\
\hline 50 years and over & 4 \\
\hline
\end{tabular}




\section{Findings}

Table 2 provides a summary of the production, consumption, and sharing of art, culture, knowledge, and benefits within the network created by the UCC.

Table 2

The Production, Consumption and Sharing of Art, Culture, Knowledge, and Benefits Within the Network of Stakeholders of a University Community Choir

\begin{tabular}{|c|c|c|}
\hline STAKEHOLDER & WHAT THEY PRODUCE AND SHARE & WHAT THEY CONSUME \\
\hline $\begin{array}{l}\text { Music/Education } \\
\text { Faculty } \\
\text { (Conductor) }\end{array}$ & $\begin{array}{l}\text { - Expertise, professional skills } \\
\text { and knowledge, and paid } \\
\text { time } \\
\text { - Connections to academic and } \\
\text { professional networks }\end{array}$ & $\begin{array}{l}\text { - Opportunities for } \\
\text { research, scholarly/ } \\
\text { creative activity, service } \\
\text { - Opportunities to } \\
\text { expand musically and } \\
\text { professionally } \\
\text { - Involvement with the } \\
\text { broader community }\end{array}$ \\
\hline University & $\begin{array}{l}\text { - Professional leaders and } \\
\text { academic expertise } \\
\text { - Facilities and equipment } \\
\text { - } \text { Funding (subsidization) and } \\
\text { support } \\
\text { - Continuing education } \\
\text { opportunities }\end{array}$ & 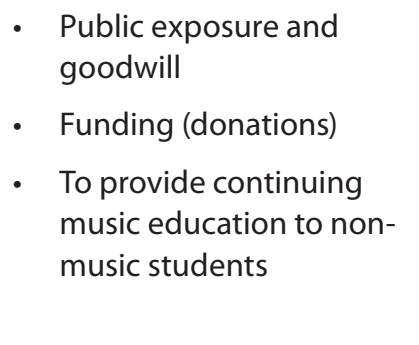 \\
\hline $\begin{array}{l}\text { Community } \\
\text { Institution } \\
\text { (Local church) }\end{array}$ & $\begin{array}{l}\text { - } \text { Facilities and equipment } \\
\text { - } \quad \text { Logistical support }\end{array}$ & $\begin{array}{l}\text { Public exposure, traffic, } \\
\text { and goodwill } \\
\text { - Funding (fees and } \\
\text { donations) }\end{array}$ \\
\hline $\begin{array}{l}\text { Choristers: } \\
\text { Community } \\
\text { (Adult) }\end{array}$ & $\begin{array}{l}\text { - } \text { Time, effort, and engagement } \\
\text { - } \text { Funds (fees and donations) } \\
\text { - } \quad \text { Critls and knowledge } \\
\text { - } \text { university-community choirs } \\
\text { - } \quad \text { Sole modeling for students } \\
\text { - }\end{array}$ & $\begin{array}{l}\text { - Continuing education } \\
\text { - } \text { Continuing music } \\
\text { - Commution and experience } \\
\text { - Recreation and serious } \\
\text { leisure } \\
\text { - Continued activity, } \\
\text { involvement, utility, and } \\
\text { contribution (seniors) }\end{array}$ \\
\hline
\end{tabular}


The Production, Consumption, and Sharing of Art, Knowledge, and Benefits Within the Network of a University-Community Choir

\begin{tabular}{|c|c|c|}
\hline STAKEHOLDER & WHAT THEY PRODUCE AND SHARE & WHAT THEY CONSUME \\
\hline $\begin{array}{l}\text { Choristers: } \\
\text { Community } \\
\text { (Youth) }\end{array}$ & $\begin{array}{l}\text { - Energy and talent } \\
\text { - Vocal vitality and lowered } \\
\text { average age } \\
\text { - Critical mass for small } \\
\text { university-community choirs }\end{array}$ & $\begin{array}{ll}\text { - } & \text { Music learning } \\
\text { opportunities beyond } \\
\text { school music } \\
\text { - } & \text { Role models } \\
\text { - } & \text { Social networks }\end{array}$ \\
\hline $\begin{array}{l}\text { Choristers: } \\
\text { (Non-music) } \\
\text { University } \\
\text { Students }\end{array}$ & $\begin{array}{l}\text { - Energy and talent } \\
\text { - Vocal vitality and lowered } \\
\text { average age } \\
\text { - Critical mass for small } \\
\text { university-community choirs }\end{array}$ & $\begin{array}{l}\text { - Opportunities for } \\
\text { continuing music } \\
\text { education } \\
\text { - Community/fellowship } \\
\text { - } \begin{array}{l}\text { Recreation and serious } \\
\text { leisure }\end{array}\end{array}$ \\
\hline $\begin{array}{l}\text { Choristers: } \\
\text { University Staff } \\
\text { and Faculty }\end{array}$ & $\begin{array}{l}\text { - } \begin{array}{l}\text { Professional skills, knowledge, } \\
\text { - }\end{array} \text { Funding } \\
\text { - } \quad \text { Logistical support } \\
\text { - } \text { Role modeling } \\
\text { - Social networks }\end{array}$ & $\begin{array}{l}\text { - Opportunities for } \\
\text { continued music } \\
\text { education and experience } \\
\text { - Opportunities for service } \\
\text { - Community within the } \\
\text { workplace } \\
\text { - Involvement with the } \\
\text { broader community }\end{array}$ \\
\hline $\begin{array}{l}\text { Community } \\
\text { Volunteers and } \\
\text { Supporters }\end{array}$ & $\begin{array}{l}\text { - Professional skills, knowledge, } \\
\text { and time } \\
\text { - Logistical support } \\
\text { - Funds (donations) }\end{array}$ & $\begin{array}{l}\text { - Continuing music } \\
\text { education, entertainment, } \\
\text { and recreation }\end{array}$ \\
\hline $\begin{array}{l}\text { Other } \\
\text { Community } \\
\text { Music and Arts } \\
\text { Stakeholders }\end{array}$ & $\begin{array}{l}\text { - Cross-promotion for } \\
\text { recruiting, performances, and } \\
\text { fundraising } \\
\text { - Supporting musicians (NBSO) } \\
\text { - } \text { Audience }\end{array}$ & $\begin{array}{l}\text { Cross-promotion for } \\
\text { recruiting, performances, } \\
\text { and fundraising }\end{array}$ \\
\hline Audience & 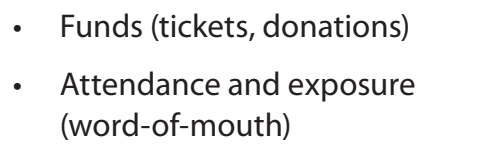 & $\begin{array}{l}\text { - Continuing music } \\
\text { education, entertainment, } \\
\text { and recreation }\end{array}$ \\
\hline
\end{tabular}


Our analysis identified six themes and 10 distinct stakeholder groups. The themes we identified were:

1) Enabling the Artist-Researcher-Teacher

2) Bridging tower and town

3) Engaging the community for mutual benefit

4) Maintaining music in postsecondary liberal arts education

5) Facilitating lifelong music learning and serious leisure

6) Cultivating future artists

We identified the university, the artistic director/conductor, community institutions, volunteers, adult community choristers, youth community choristers, (non-music) university students, university staff and faculty, the audience, and other community music and non-music artists as stakeholders. We discuss the findings for each theme and stakeholder group in greater detail below.

\section{Enabling the Artist-Researcher-Teacher}

The artistic director of the UCC is appointed in the faculty of education at Nipissing University. As stipulated by the faculty association's collective agreement, $40 \%$ of each faculty member's job is teaching. Nipissing University does not have a curricular music program in which to find more diverse and challenging teaching opportunities. Apart from courses in music education methods for teacher candidates, the faculty member does not currently have opportunities to teach music courses at the postsecondary level (e.g., conducting, choral literature, composition, and arranging) that would support his continued development as a university teacher and professional musician. The faculty member explained, saying, "It's important to me to maintain my identity as a practicing musician, conducting being my main applied area."

Also stipulated in the collective agreement is that $40 \%$ of each faculty member's job should be devoted to research, scholarly work, and/or creative activities. Sefton and Bayley (2012) discuss the "simultaneous reflexivity between roles as artist, researcher, educator" (p. 325) that occur for the Artist-Researcher-Teacher. Postsecondary music educators who are also skilled musicians have the ability to "(move) past just talking or thinking about music to envisioning a creative work and engaging in the act of making music" (p. 328). Their engagement in scholarly performance and subsequent scholarly works which emerge from it informs education culture and practice within the faculty of education and gives "pedagogical legitimacy" (p. 329) to their teaching. Working with a UCC provides the music 
education professor with opportunities to teach music at the university level while engaging in research, scholarly and creative work, and contributing to campus and community service. The faculty member explained,

The music I choose is not for entertainment. There are different reasons for choosing repertoire. For some it's to have a fun time with the singers and to provide an entertaining experience for the community; whereas for me, it's to produce art and if the audience are hopefully entertained by that ... If the quality of repertoire is good ... but the entertainment factor-it's a by-product, it's secondary.

This music education professor is the central coordinating figure and driving force behind the UCC, pulling all the stakeholders together. Specifically, this faculty member also acts as an executive director for the UCC, thereby acting in both an artistic and managerial role. As the faculty member explained,

On the artistic director side, it's having a vision and then planning activities to maintain that vision... which means choosing repertoire that's in keeping with the vision, preparing the repertoire, and teaching it. ...Then facilitating and directing performances ... serving as the key representative of the organization in the community, and linking with other arts groups, ... and then sometimes choosing the performing forces, outside performing forces, and then that sort of moves over to the executive director side where it's the business side of things, which is contracting performers and paying them, handling all the financial planning aspects, both in terms of planning and the paperwork after the fact to make sure bills are paid, maintaining and budget ... and basically overseeing the whole operation even though there are other people who are doing jobs, ... there's a managerial role of the volunteer staff, liaising with the partner organizations ... and, in some cases, grant writing.

By using the UCC as a vehicle for research, scholarly work, creative activity, and/or service as part of his employment with the university, the need to provide a separate salary to the conductor or executive director of the UCC, as would be customary for non-university community choirs, is eliminated. In this way, the university subsidizes the ensemble by paying the salary of its conductor, which is one of the principal expenses for any community choir. Honoraria or salaries for conductors of small community choirs typically range from $\$ 5,000$ to $\$ 15,000$, but can extend higher for conductors of larger community choirs or those with a strong audience base. In most cases, conductors of community choirs take other 
jobs as well (e.g., school teacher, church music director, university professor, private studio teacher), with their community choir job constituting secondary income. This does not preclude the conductor of the UCC from taking an honorarium for his services, particularly when the amount of time invested extends beyond the portion of his research, scholarly work, creative activity, and service time he has allotted to the activity. The faculty member's access to the university's facilities to conduct his research, scholarly, and creative activity further subsidizes the UCC's operations by eliminating fees for rehearsal space. This helps to keep member fees low to make the activity accessible, and reduces the need for operating grants. One challenge for a UCC is that by its association with a university and a faculty member's scholarly output, it is precluded from applying for most operating grants. However, even for community choirs that are independent and incorporated, applying for grants can be onerous.

The process of rehearsing and performing with a UCC provides the faculty member with the opportunity to engage in research and to disseminate that research in the form of teaching and performance. Historical and theoretical research into composers and works, historical periods and practices, musical cultures and practices, and cultural implications of works all inform the conductor's teaching of the works to his choir. Choristers also learn breathing and vocal production, languages and diction, aural and sight-reading skills, and theoretical understanding. One chorister commented, "I am not an expert, but this choir was an opportunity to be coached by an expert," while another said, "it has assisted me to improve my voice and push myself to places I never thought I would be capable vocally." The UCC allows the faculty member to model choral pedagogy and conducting techniques for his education students (i.e., he practices what he teaches). Finally, the UCC allows the faculty member to connect with his education students and with students from other programs in deeper and more meaningful ways, crossing instructor-student boundaries, as they become co-performers, co-constructors, and disseminators of knowledge.

Concerts serve as a venue for dissemination of the conductor's research and as the culminating activity where choristers collectively share what they have learned, synthesized into performance. The conductor and choristers become a "teaching team" that mobilizes knowledge beyond the boundaries of academia by taking that knowledge directly to the community, in a form that is understandable, meaningful, and impactful. Academic research is typically disseminated through scholarly presentations and publications, and through faculty members' teaching. This contributes to the tower-town gap as members of the community do not 
see the immediate benefit or value of that research. Supporting the performance, the conductor provides periodic lecture components (direct teaching) as well as detailed program notes that support the audience's understanding of the socio-cultural and compositional implications of the repertoire being performed, along with the conductor's process of conceptualizing the performance project and how his choices of repertoire are linked to an artistic theme or question. By teaching the audience what to actively listen for, their listening/viewing experience is framed by a deeper understanding that helps them to conceptualize that experience. Over time, the audience becomes more musically informed and open to novel and increasingly complex music experiences.

\section{Bridging Tower and Town}

The university's location at the top of a hill on the edge of the city is such that it is geographically and socially isolated from the rest of the community. Community members do not see much of the university or go there as often as they would if the university was located in the downtown core. Despite the fact that the university engages in many forms of community outreach, there is still a lack of awareness in the community as to what goes on at the university or of the many programs of research conducted by the faculty. The UCC brings scholarly creative activity to the community, who are able to see and enjoy the benefits directly, with a consequent positive impact on the university's image in the community.

Referring to NNV's Voices of Light project in 2010, the then Nipissing University president, Dr. Lesley Lovett-Doust (2010), published an op-ed in the local newspaper in which she wrote,

The Voices of Light project engaged faculty in a series of discussions, exhibitions, and presentations, culminating in this outstanding production. It was a wonderful celebration of the connection between scholarship, creativity and community that celebrates the true meaning of the teacher/scholar set in the context of our community and culture.

The audience is a critical piece of the university-community relationship; it gives a reason to learn and perform music. Audience satisfaction enhances the choir's goal of teaching and learning. Obviously, the audience provides much-needed ticket proceeds that partially pay for the expenses of concert production and they make donations that help pay for the UCC's operating expenses. In return, what they get is a musical experience that is recreational and educational, particularly given the 
basis of the repertoire in western art, folk, and world music that sets the UCC apart from other local community choirs. One chorister commented, "I think the goal is to present a type of music to the community that they don't get otherwise. Because the repertoire is odd, it's a good odd," while another felt that "the high level of performance, music, and enjoyment will most likely bring audiences back." One community partner noted that the "community is extremely happy to be able to attend this type of concert that we normally would have to drive to Toronto to see/hear. That is why the concert is always sold out before the day of the concert."

\section{Engaging the Community for Mutual Benefit}

Beginning in the UCC's second season, the director entered into a partnership with a local church, hitherto referred to as the "Church." The Church has concert space with excellent acoustics available and it is vacant much of the time. The Church also has a strong music program and its congregation is highly supportive of music and the arts in general. The congregation provides a core audience for the UCC's concerts and performances as well as word-of-mouth promotion. The Church is also a key source of audience donations as well as ticketing booth, ushering, and back-stage volunteers for concerts. Donations represent approximately $16 \%$ of the UCC's revenues. There are typically seven volunteers per concert who together donate more than 22 hours of total volunteer hours per concert-approximately $\$ 660$ in volunteer hours per season.

The Church's connections with other local churches further facilitate concert promotion. The congregation supplies elaborate post-concert receptions that further enhance choir-community fellowship. Direct support from the Church's music director, minister, staff, and committees reduces much of the administrative and logistical stress normally associated with using an outside organization's concert space. The welcome they provide contributes to the fellowship and sense of community that the choir feels and enjoys. The Church charges relatively little $(\$ 350)$ for the use of space for dress rehearsals and concerts, subsidizing that aspect of the choir's operating budget, and providing a "cushion" that reduces stress around concert attendance and ticket sales. Whenever possible, the choir "tops up" its fees to the Church with additional donations that contribute to the Church's operating budget.

Additional benefits beyond the financial accrue to the Church from this partnership. The UCC enhances the music program at the Church, while also bringing the wider community into the building. For some students who are living away from home and from their home churches, this has become an important connection. 
Improvements made to the Church's sanctuary (additional choral risers, improved lighting) as a result of the UCC's presence have encouraged and enhanced performances by several other community ensembles, making the Church a "community concert hall," generating additional income for the Church. UCC concerts have also been a venue for cross-promotion of the Church's activities and fundraising efforts. One volunteer from the Church stated that they see working with the UCC as part of their outreach ministry to the community, allowing the Church to fulfill part of its mission.

The city's multiple choral and instrumental ensembles share an audience and share talent-the city's limited concert attending and/or music-making population. Regular cross-promotion supports the recruiting of musicians, promotion of concerts and fundraising events, while reducing these groups' promotional expenses. This also extends to the visual arts and theatre communities, which to a large extent share the same audience. The UCC also provides a venue for individual musicians and smaller musical ensembles to showcase their talents. The UCC often partners with smaller musical ensembles to co-host concerts, relieving the pressure on these smaller musical ensembles to fully finance and put together enough repertoire for an entire concert. The UCC invites both local musicians and musicians from outside the community to participate in its concerts. One guest musician was grateful for the "ability to perform larger works," while another remarked that, "Performing as a guest artist outside the community gives the community the opportunity to hear someone new that they otherwise might not have heard, and strengthens ties between artists from various artistic communities which may lead to further collaborations."

While many of the guest instrumentalists and vocalists receive an honorarium (ranging from \$200 to more than \$500) for their participation in the UCC's concerts, many volunteer their time and talent. Eight of the 19 instrumentalists and guest vocalists that participated in our survey volunteered their time (some receiving an unexpected honorarium), while seven negotiated an honorarium. One community partner who recognized this benefit stated,

North Bay and surrounding areas have a thriving arts community that is further enriched by having NNV. It is a great outlet for our talented people and it provides them with opportunities that they may not have had otherwise. NNV partners with local groups and brings in a wide variety of groups from all over, even as far as the States. 


\section{Maintaining Music in Postsecondary Liberal Arts Education}

As previously stated, the university does not have a curricular music program. While students were able to continue musical involvement and learning at the university, the limited offering of music option courses was suspended in 2012 due to funding constraints. Given the well-established culture of lifelong music learning, engagement, and appreciation in North Bay and area, these cuts were not well received in the community. Although the university has strong and well-funded extracurricular athletics programs, it currently offers nothing by way of extracurricular music activities at a level commensurate with other higher education institutions. The UCC affords a musical opportunity that supports student recruitment and retention by allowing students who are pursuing non-music areas of study to continue their music education.

In the absence of elective music courses at the university, the UCC provides university students with the opportunity to continue their music education through the learning and performance of advanced repertoire at a level commensurate with postsecondary music programs, while developing leadership skills and building their record of achievement and curricula vitae. For students in the university's Bachelor of Education program whose subject is music, participation in the UCC exposes them to a model of choral and vocal pedagogy with a mixed-ability group, and provides opportunities for guided conducting and rehearsing. One participant stated, "I learned a lot about music, the theory of music, the pedagogy of music," while another said, "I have been able to observe how to run a community choir, lead vocal warm-ups, and it has helped my sense of pitch."

The UCC is a venue for fellowship with peers outside of these students' immediate academic programs, where mentoring and role modeling is provided by faculty, staff, and adult community choristers. It also brings them into the local community beyond campus, adding to the breadth and quality of their postsecondary experience. As choristers, university students lower the average age of the group, providing vocal vitality and focus that supports and helps to improve the vocal limitations of some of the older voices, facilitating the learning and performance of more challenging repertoire that might not be possible with a typical (non-university) community choir.

\section{Facilitating Lifelong Music Learning and Serious Leisure}

The adult (non-student) community members of the UCC constitute two-thirds of the choir's membership. They are working professionals and retirees, ranging in 
age from early 20 s to 81 . The least represented group are adults in the 30 s and early 40 s - the primary working and parenting years, when individuals may not have the time available to commit to this activity. The adults bring varying levels of musical expertise to the ensemble, ranging from amateur to professional. Their voices contribute to the choir's critical mass, facilitating the performance of larger and more complex works. They provide a sense of community and connection to the community for the students, and a sense of caring and oversight that is missed by some students while away from home. Their engagement serves as a role model for learning-for-life and music-for-life for the students. In addition, adult members are given the opportunity to donate to the choir to subsidize the membership fees and other related expenses of the students. Many also contribute regularly to the choir's operating budget through additional donations. Adult members comprise the majority of the choir's advisory group. Advisory group members take on more active roles to facilitate the choir's operations. As of 2016, 25\% of the choir's members were involved in the advisory group. Altogether, advisory group members contribute $\$ 3500$ in volunteer hours per season.

Adult respondents described deriving recreation and leisure from the activity, along with ongoing musical growth and learning, development and strengthening of their voices, aesthetic satisfaction, and a sense of satisfaction and pride as the result of both rising to learning challenges and the successful performance of challenging works. Many described the UCC as a community or a "choir family." For some this choir family is amongst multiple communities of interest that they are engaged in. For most of the adult choristers, their participation in the UCC constitutes serious leisure involving the need to persevere and make significant personal effort, while experiencing stages of achievement, durable benefits (such as renewal), a unique ethos, and a strong identification with the choir and its activities. One chorister commented, "I think participating in the choir is a privilege and I was able to contribute to the whole." Another chorister remarked, "Singing with NNV provides the musical challenge I seek, gives me immense enjoyment, satisfaction when I am successful, tremendous pleasure in providing quality music for our community, opportunity to interact with a younger student population."

The value that choristers receive is evidenced by the time, money, and commitment to this endeavour. In 2015, the membership fee for the UCC adult choristers was $\$ 80$. Seventy-six percent of choristers thought that this membership fee was reasonable or appropriate, with another $16.7 \%$ thinking that it was too low. A common approach is to assume that the marginal value of leisure time is a fraction of the wage, with one-quarter or one-half often used in 
practice (e.g., Bowker et al., 1996). The majority of choristers indicated that they spent two to five hours per week practicing outside of the two hours of weekly rehearsal for the 26-week performance season. In addition, the majority of choristers attended the eight-hour annual retreat. The estimated value of the leisure received by each chorister ranged between $\$ 470$ and $\$ 1445$ per season.

\section{Cultivating Future Artists}

Over the years, the UCC has welcomed a number of secondary school students. All have been heavily involved in their school music programs as well as other, youth-oriented musical theatre activities in the community. The UCC created a student choral scholarship that rewards secondary students who contribute significantly to the choir's musical efforts, and who demonstrate substantial musical growth over the season. This scholarship is provided more as an award than as a recruitment incentive, and has supported a number of students as they have gone on to study music at the postsecondary level. The scholarship is funded by donations from adult choristers, along with the proceeds from silent auctions of donated goods from local businesses.

The high school students bring energy to the ensemble and, by lowering the average age, also contribute to the vocal quality of the group. They receive a more formal and rigorous music education experience than they do in their high school music classes. The more challenging repertoire of the UCC - based in historical and contemporary western art music, folk, and world music_facilitates development of sight reading and oral skills, a broad general musical knowledge, and vocal growth and technique that can support auditioning for conservatory-based university music programs.

\section{Conclusion}

Some of the benefits of the UCC identified in our study include its ability to enable the artist-researcher-teacher, its ability to provide the means to keep music in postsecondary liberal arts education when resources are limited, and its ability to facilitate lifelong music learning, serious leisure, and cultivate future artists. As evidenced in our findings, the UCC solves many of the challenges experienced by many traditional community choirs by removing some of the financial constraints as well as challenges of recruiting and retention-particularly of younger singers- 
that can negatively affect their success. The UCC fulfills the university's need to provide a music education experience for their students with minimal financial commitment from the university, while addressing the challenges of recruiting and retention that can negatively affect a university choir on a campus with no music program. Both the community's and the university's resources (e.g., talent, expertise, facilities) are better used through the UCC.

The UCC also creates a continuing education program with minimal investment from the university that brings active community involvement to campus and supports public goodwill. The serious leisure and recreation provided by the UCC and performances of the UCC provide durable benefits and contribute to culture both on campus and in the community. Most importantly, the UCC meets the musicmaking and music-educational needs of multiple stakeholders both on campus and in the community, and does so in a way that actively links tower and town, while bringing together diverse participants in a shared community of practice. In this study, we sought the perspectives of community members on a form of community engagement in which community members are given access to university resources (e.g., expertise, rehearsal space), adding to the limited literature in this area. More research is needed on the perspectives of community members in terms of townand-gown relations. In addition, we have added to the limited literature on concerted singing as a leisure activity.

\section{References}

A Delicate Balance: Music Education in Canadian Schools Executive Summary. (2010). Canadian Music Educator / Musicien Educateur au Canada, 52(2), 28-31.

Adderley C., Kennedy, M., \& Berz W. (2003). "A home away from home": The world of the high school music classroom. Journal of Research in Music Education, 51(3), 190-205. doi:10.2307/3345373

Beynon, C. (2003). The rise and fall and rise... of choral music education in Canada. Canadian Music Educator, 45(3), Winter 2003, 29-31.
Bogdan, R. C., \& Biklen, S. K. (2007). Qualitative research for education: An introduction to theory and methods (5th ed.). Boston: Pearson.

Bowers, J. (1999). Effects of an intergenerational choir for community-based seniors and college students on age-related attitudes. Journal of Music Therapy, 35, 2-18.

Bowker, J.M., English, D.B.K., \& Donovan, J.A. (1996). Toward a value for guided rafting on southern rivers. Journal of Agricultural and Applied Economics, 28, 423-432. doi:10.1017/ S1074070800007410. 
Bruning, S. D., McGrew, S., \& Cooper, M. (2006). Town-gown relationships: Exploring university-community engagement from the perspective of community members. Public Relations Review, 32(2), 125-130. doi:10.1016/j.pubrev.2006.02.005

Cesario, F.J. (1976). Value of time in recreation benefit studies. Land Economics, 52, 32-41.

Conway, C., \& Hodgman, T. M. (2008). College and community choir member experiences in a collaborative intergenerational performance project. Journal of Research in Music Education, 56(3), 220-237. doi:10.1177/0022429408327297

Darrow, A. A., Johnson, C. M., \& Ollenberger, T. (1994). The effect of participation in an intergenerational choir on teens' and older persons' cross-age attitudes. Journal of Music Therapy, 31, 119-134.

Davis, C. (2012). Community choir enhances coping skills and quality of life. Cancer Nursing Practice, 11(1), 30-31.

Douglas, S., \& Willatts, P. (1994). The relationship between musical ability and literacy skill. Journal of Research in Reading, 17, 99-107.

Freer, P. K. (2009). 'I'll sing with my buddies'-Fostering the possible selves of male choral singers. International Journal of Music Education, 27, 341-355. doi:10.1177/0255761409345918

Freer, P. K., \& Tan, L. (2014). The self-perceptions of young men as singers in Singaporean pre-university schools. Research Studies in Music Education, 36, 165-178. doi:10.1177/ $1321103 \times 14556575$

Gardiner, M. E., Fox, A., Knowles, F., \& Jeffrey, D. (1996). Learning improved by arts training. Nature, 381(6580), 284.

Hetland, L. (2000). Listening to music enhances spatial-temporal reasoning: Evidence for the Mozart effect. The Journal of Aesthetic Education, 34(3-4), 105-148.

Johnson, J. K. et al. (2013). Quality of life (QOL) of older adult community choral singers in Finland. International Psychogeriatrics, 25(7), 1055-1064. doi:10.1017/S1041610213000422
Joseph, D., \& Southcott, J. (2015). Singing and companionship in the Hawthorn University of the Third-Age Choir, Australia. International Journal of Lifelong Education, 34(3), 334-347. doi:10.1080/02601370.2014.9 91951

Kemp, R. L. (2014). Town and gown relations revitalize America's downtowns. National Civic Review, 103(2), 27-29. doi:10.1002/ ncr.21190

Kennedy M. C. (2004). "It's a metamorphosis": Guiding the voice change at the American Boychoir School. Journal of Research in Music Education, 52, 264-280. doi:10.2307/3345859

Kokotsaki, D., \& Hallam, S. (2007). Higher education music students' perceptions of the benefits of participative music making. Music Education Research, 9(1), 93-109. doi:10.1080/14613800601127577

Langston, T. W., \& Barrett, M. S. (2008). Capitalizing on community music: A case study of the manifestation of social capital in a community choir. Research Studies in Music Education, 30(2), 118-138. doi:10.1177/1321103X08097503

Larson, D.M., Shaikh, S.L., \& Layton, D.F. (2004). Revealing preferences for leisure time from stated preference data. American Journal of Agricultural Economics, 86(2), 307-320.

Liu, H., \& Stebbins, R.A. (2014). Concerted singing: Leisure fulfilment in a university faculty chorus. Leisure Studies, 33(5), 533-545.

Lovett-Doust, L. (2010, February 2). Passion for the arts is alive and well in North Bay [Opinion Letter]. North Bay Nugget. Retrieved from http://www.nugget.ca/2010/02/02/passion -for-the-arts-alive-and-well-in-north-bayletter

Macdonald, R. A. R. (2013). Music, health, and well-being: A review. International Journal of Qualitative Studies in Health and Well-Being, 8, 1-13. doi:10.3402/QHW.V8I0.20635

Mayfield, L. (2001). Town and gown in America: Some historical and institutional issues of the engaged university. Education for Health, $14,231-240$. 
McQueen, H., Hallam, S., Creech, A., \& Varvarigou, A. (2013). A philosophical perspective on leading music activities for the over 50 s. International Journal of Lifelong Education, 32, 353-377.

Meisenbach, R. J., \& Kramer, M. W. (2014). Exploring nested identities: Voluntary membership, social category identity, and identification in a community choir. Management Communication Quarterly, 28(2), 187-213. doi:10.1177/0893318914524 059

Mullin, J., Kotval-K, Z., \& Cooper, J. (2012). The university and local economic development. Transylvanian Review of Administrative Sciences, 8(SI), 126-136. Retrieved from http://rtsa.ro/tras/index.php/tras/article/ view/325/318

Mullins, R. L., \& Gilderbloom, J. I. (2002). Urban revitalization partnerships: Perceptions of the university's role in Louisville, Kentucky. Local Environment, 7, 163-176.

Parker, E. C. (2014). The process of social identity development in adolescent high school choral singers: A grounded theory. Journal of Research in Music Education, 62, 18-32. doi:10.1177/0022429413520009

Parker, E. C. (2016). The experience of creating community. Journal of Research in Music Education, 64(2), 220-237. doi:10.1177/0022429416648292

Patton, M. Q. (1990). Qualitative evaluation and research methods (2nd ed.). Newbury Park, CA: Sage.
Phaneuf, D.J. (1999). A dual approach to modeling corner solutions in recreation demand. Journal of Environmental Economics and Management, 37, 85-105.

Sayer, R. (2010). A place for everyone in the choir. Choral Journal, 50(7), 47.

Schellenberg, E. G. (2004) Music lessons enhance IQ. Psychological Science, 15(8), 511-514.

Sefton, T., \& Bayley, J. (2012). The performing professor: Conflicts of identity and work in faculties of education. In O'Neill, S. (Ed.) Personhood \& music learning: Connecting perspectives and narratives (pp. 319-337). Canadian Music Educators' Association.

Skingley, A., \& Bungay, H. (2010). The silver song club project: Singing to promote the health of older people. British Journal of Community Nursing, 15, 135-140.

Statistics Canada. (2012). Focus on Geography Series, 2011 Census. Statistics Canada Catalogue no. 98-310-XWE2011004. Ottawa, Ontario. Analytical products, 2011 Census. Last updated October 24, 2012.

Stebbins, R.A. (1982). Serious leisure: A conceptual statement. Pacific Sociological Review, 25, 251-272.

Veblen, K., \& Olsson, B. (2002). Community music: Toward an international overview. In R. Colwell \& C. Richardson (Eds.), The new handbook of research on music learning and teaching (pp. 730-756). New York: Oxford University Press. 


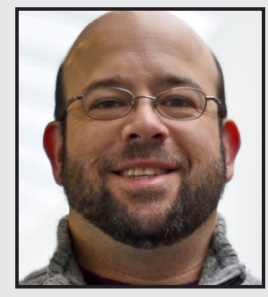

Adam Adler is Assistant Professor of Music Education at Nipissing University; he taught previously at the University of Windsor, the Crane School Music (SUNY Potsdam), and in the public school system. His scholarly interests include narrative and arts-based research, male gender in music education, and choral communities. He is the founding director of Near North Voices-North Bay's University-Community Choir, and previously directed the Ford Motor Company Chorus (Dearborn), Crane Men's Ensemble and Crane Chorus (Potsdam), Just Singers (Toronto), University of Toronto Hart House Singers, and Centenary United Church Choir (Hamilton). $\mathrm{He}$ is active as a clinician, adjudicator, composer, and arranger.

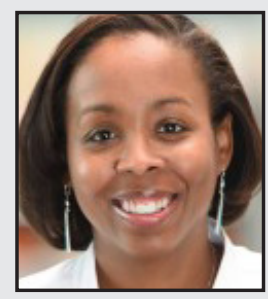

Natalya R. Brown is an Associate Professor of Economics in the School of Business and the Department of Political Science, Philosophy, and Economics at Nipissing University. Her current research interests are in political economy, management education, sustainable tourism, financial literacy, and immigrant success. Natalya is also an active member of the North Bay community, volunteering her time with various community organizations including the Nipissing Transition House and the North Bay and District Multicultural Centre. She is also a member of J.O.Y. Band TOO! - a community concert band-in which she plays trombone. 